\title{
The introduction section of research articles in English and Turkish: The case of educational sciences - a preliminary study
}

\author{
Tanju Deveci a* (D) \\ a Tanju Deveci, Khalifa University, Abu Dhabi 2533, UAE \\ Received 3 September 2019 | Received in revised form 27 November 2019 | Accepted 5 December 2019
}

\section{APA Citation:}

Deveci, T. (2020). The introduction section of research articles in English and Turkish: The case of educational sciences - a preliminary study. Eurasian Journal of Applied Linguistics, 6(1), 119-140.

Doi: 10.32601/ejal.710233

\begin{abstract}
Readers' decisions about the relevance and significance of research presented in a journal article are often influenced by the introduction section. Several factors contribute to authors' writing of effective introductions. This descriptive study aimed to explore strategies used by English and Turkish authors in the introduction section of educational sciences research articles published between 2012 and 2018. Towards this end, the creation of a research space (CARS) model and authorial voice were investigated in a 358,068-word collection of 62 journal articles (31 Turkish \& 31 English). Results showed that the English collection revealed more frequent use of the submoves in CARS. Additionally, it included other moves (i.e., announcing principal findings and description of the methodology used) which were absent in the Turkish collection of text. The authors of the English introductions and those of the Turkish introductions also differed from each other significantly in their use of authorial voice. The former used the active voice more often than the passive voice. There was also some use of personal pronouns in the English texts while they were never used in the Turkish texts. These results point to a general pattern in education research article introductions in English and Turkish. The results imply that authors' lack of attention to these trends when writing in a foreign language may result in limited visibility in their fields. It is, therefore, recommended that scholars and training students should be informed about the ways they could navigate these issues within their discourse communities.
\end{abstract}

(C) 2020 EJAL \& the Authors. Published by Eurasian Journal of Applied Linguistics (EJAL). This is an open-access article distributed under the terms and conditions of the Creative Commons Attribution license (CC BY-NC-ND) (http://creativecommons.org/licenses/by-nc-nd/4.0/).

Keywords: Authorial voice; CARS model; education research articles; introduction

\section{Introduction}

The introduction section of a research article (RA) plays a key role in establishing the significance of the research conducted. An effective introduction puts the research topic in perspective for the readers. It is often this section, after the abstract, that makes the readers decide whether the whole text is relevant. In this regard, the introduction section merits careful attention. To support authors' effective writing of this section, Swales and Feak (2012) developed "the Create-a-Reseach-Space Model"

\footnotetext{
* Corresponding author. Tel.: +971-056-283-1243

E-mail address: tanjudeveci@yahoo.com

http://dx.doi.org/10.32601/ejal.710233
} 
(CARS), which has been used extensively to analyze introductions in research articles (RAs) in a variety of scientific disciplines in English (e.g., Samraj, 2002; Öztürk, 2007; Rahman, Darus, \& Amir, 2017). Some research has also been conducted in other languages such as Brazilian Portuguese (Hirano, 2009), Hungarian (Arvay \& Tanko, 2004), Chinese (Loi \& Evans, 2010), and Spanish (Sheldon, 2011). These were often comparative studies aiming to identify how authors write in English and their native languages.

Whether they be native or non-native, authors need a complete understanding of the conventions governing written academic discourse within their discourse communities (Chandrasegara, 2012). Otherwise, their communication with the audience will suffer. Despite this, full awareness of conventions in a given discourse community is still no panacea, especially for those who write in a language other than their native one. Research has revealed that writing in English as a foreign language required more cognitive effort, and papers produced by authors for whom English was a foreign language were not on a par with the expectations of the English language research community (van Weijen, 2014). To understand the challenges faced by such authors, a plethora of research has focused on language issues in scholarly work. Towards this end, researchers have investigated particular sections of RAs such as abstract (e.g., Kafes, 2012), method (e.g., Deveci \& Nunn, 2020), and discussion (e.g., Jalilifar, Hayati, \& Namdari, 2012). However, relatively less attention has been paid to the introduction section despite its heavy influence on the readers' decision about the relevance and worthiness of the article as a whole. It also seems that the introduction section has not been an area of interest for Turkish scholars in generaland for those in educational sciences in particular. To the author's best knowledge, there is (almost) no research devoted to the move structure in education RA introductions (RAIs).

The credibility of authors' arguments is also assessed by their use of authorial voice (Nunn, 2012). A lack of skills in creating an authorial voice likely reduces the impact on readers, causing them to dismiss the arguments made in the manuscript. It is commonly observed that authors refrain from utilizing personal pronouns for the sake of "objectivity" (Nunn, 2014, p. 28). This is often despite instructions provided by publication manuals and recent research findings indicating a trend towards more incorporation of first-person pronouns in RAs (Deveci \& Nunn, 2020; Nunn, Deveci, Khan, \& Ayish, 2018; McCallum, 2016; Carciu, 2009). This aspect of authorial voice in the introduction sections has not received much interest from researchers. Given the stigma attached to the use of personal pronouns as 'unscientific', this appears to be particularly the case among Turkish scholars. This, however, merits scientific investigations.

Responding to the lack of research into the above-mentioned aspects of scholarly publications in educational sciences, this study sought to provide answers to the following research questions: 
1. a) What is the move structure in education RAs in English?

b) What is the move structure in education RAs in Turkish?

2. a) How often do authors use the first-person pronouns for authorial voice in English?

b) How often do authors use the first-person pronouns for authorial voice in Turkish?

\section{Literature Review}

\subsection{Introduction section of $R A$ s}

The term "introduction" is derived from the verb "introduce," which is defined in the dictionary as "to lead or bring in especially for the first time" (Merriam-Webster.com, 2019). As this definition suggests, the introduction (abstract aside) is the very first place the topic is presented/introduced to readers. It provides readers the background to the topic (Shank \& Brown, 2007). In this sense, according to the American Psychological Association (2010), the introduction "presents the specific problem under study and describes the research strategy" (p. 27). Authors are advised by the Association that they sufficiently explore the importance of the problem by explicitly stating the reason why it deserves new research. This may involve the need to address any inconsistencies revealed by previous research, or the need to extend the reach of a theoretical formulation. Alternatively, the author may choose to focus on a solution to a problem or treat a disorder, as in the case of a psychological study. Authors are also warned to present different views if research is centered on a controversial issue. They are also required to state the aim of the research explicitly.

Authors are also asked to discuss the relevant literature on the topic through citation of and specific credit to related previous work in the field. This allows readers to see how the study fits in the wider context. Authors' development of the problem with adequate breadth and clarity will help the paper be understood by a wide professional audience. In doing so, authors are warned to refrain from including an exhaustive account of the literature.

Similarly, Alley (2013) notes that by the end of the introduction, readers normally expect to find answers to these questions: a) What exactly is the work? b) Why is the work important? c) What is needed to understand the work? d) How will the work be presented? However, Alley (2013) also warns that, depending on the work and the readers, an introduction may address only some of these questions. Just as the answer to these questions may not be stated explicitly, neither may they be answered in the most efficient order. He further warns that readers should not be left without answers to at least some of these questions by the time they reach the middle. Alley (2013) also states that the introduction gives authors the first chance to define the full boundaries of their work. 
Swales and Feak's (2012) investigations into RAs across disciplines revealed that introductions in research papers typically follow a pattern which they named as the create-a-research-space (CARS) model. This model is comprised of the following moves, some of which are obligatory while some others are optional (Swales \& Feak, 2012).

Move 1- Establishing a research territory

a. by showing that the general research is important, central, interesting, problematic, or relevant in some way (optional)

b. by introducing and reviewing items of previous research in the area (obligatory)

Move 2- Establishing a niche

by indicating a gap in the previous research or by extending previous knowledge in some way (obligatory)

Move 3- Occupying the niche

a. by outlining purposes or stating the nature of the present research (obligatory)

b. by listing research questions or hypotheses (possible in some fields, but rare in others)

c. by announcing principal findings (possible in some fields, but rare in others)

d. by stating the value of the present research (possible in some fields, but rare in others)

e. by indicating the structure of the research paper (possible in some fields, but rare in others)

According to Dudley-Evans (2000), the CARS model

captures the way in which academic [authors] justify and highlight their contribution to the ongoing research profile of the field by first establishing a topic for the research and summarizing the key features of the previous research, then establishing a gap or possible extension of that work that will form the basis of the [author's] claims. (p. 5)

This prompted many researchers to investigate the writing of the introduction section in different disciplines. The findings of these studies seem to indicate that there are differences between disciplines. For instance, Anthony (1999) investigated the introduction section of 12 software engineering RAs. Results showed that the classification of definitions and examples was an obligatory move, but it was missing in the original model. In addition, he noted the need for "evaluation of research" as a separate step. Similarly, Shehzad (2006) found that computer scientists indeed used a wide range of methods for establishing a research territory in the introduction. These included being part of the cult, the project reported being problematic and/or challenging, the use of definitions and descriptions.

Swales and Najjar (1987) investigated one of the moves (i.e., announcing of principal findings) in physics and education RAIs. They found that $45 \%$ of the former contained this move, while only $7 \%$ of the latter contained it. A similar finding 
appeared in Afshar, Doosti, and Movassagh's (2018) study into chemistry and applied linguistics RAIs. Of the former, $21.15 \%$ employed the move whereas none of the latter employed it. Together, these findings point to an overall trend towards announcing principal findings in hard sciences.

Afshar et al. (2018) also found that Step 1-a was present in $92.3 \%$ of chemistry RAIs. However, a niche was established with Move 2 explicitly in only $50 \%$ of the chemistry RAIs while the majority of the applied linguistics RAIs established a niche. The authors of the chemistry texts pointed to the value "by highlighting the fact that the outcome of their research would solve a problem in the real world" (p. 193). Another difference between the two disciplines was in terms of outlining the structure of the paper and definitional clarifications, which were present only in the applied linguistics RAIs. Other previous research, too, had revealed that chemistry RAIs did not include this move (Stoller \& Robinson, 2013). The qualitative data from interviews by Afshar et al. (2018) showed that chemistry authors refrained from providing definitional clarifications due to the belief that "the research articles are often read by the members of the community who are experts in the field and are already familiar with the technical terms, hence defining them seems redundant and unnecessary" (p. 205).

There are also differences within a discipline. To exemplify, Adika (2014) investigated the use of the CARS model in RAs in a particular humanities journal. The sub-disciplines covered in the study included Language and Linguistics, Literature, History, Education, Performing Arts, Philosophy, and Religions. Results showed that there were variations between the authors' utilization of the RAIs from different sub-disciplines. However, an overall finding was that the authors generally tended not to review items of previous research (Move 1-b), failing to reinforce the research niche expressed in Move 2. In another humanities-related study, Habibie (2008) found that authors from English for Specific Purposes, Sociolinguistics and Psycholinguistics did not follow the CARS model rigidly, and there were variations between the subdisciplines. Deviation from the original model was found to be the case in Social Science RAs as well, which often included authors' using cycles of moves (Crookes, 1986). With these in mind, it could be suggested that "there will always be exceptions to the general pattern; [authors] will choose to omit a particular Move or vary the order of Moves or Steps to suit their particular rhetorical purpose" (DudleyEvans, 2000, p. 6).

\subsection{Use of first-person pronouns in RAs}

From the perspective of journal editors and reviewers, Cargill and O'Connor (2013) state that the introduction is of particular importance since it is this section they first look at to identify whether the author's contribution is new and significant and whether the paper is suitable for publication for their journal. To meet this criterion, authors ought to pay special attention to emphasizing the necessity of their research, in other words, their contribution to the field. Among various ways of doing this is 
authors' transitivity choices to express agency. One way transitivity can be achieved is through the use of first-person pronouns and the active voice. By using first-person pronouns, authors perform a strategic move to highlight their original contribution to literature (Nunn, 2014; Nunn, Deveci, Ikhlas, \& Ayish, 2018). In our previous study, we concluded that "some degree of subjective intervention [one way of which is to use personal pronouns] alongside intersubjective argumentation is inevitable, and can, therefore, be exposed and displayed transparently," and such transparent authorial intervention allows the readers "to work out what can be retained and relied upon for future study" (Nunn et al., 2018, p. 97).

Top journals such as Nature and Science explicitly recommend authors to avoid impersonal language for a more transparent approach to agency (Nunn, Brandt \& Deveci, 2018). Similarly, The Publication Manual of the American Psychological Association (APA) (2010) cautions that authors ought to avoid ambiguity. This can be achieved by "us[ing] a personal pronoun rather than the third person when describing steps taken in [their] experiment" (p. 69). It is pointed out in the manual that for the sake of being objective, inappropriate or illogical attribution of an action can be misleading. Despite this, anecdotal evidence shows that Turkish scholars are particularly apprehensive about utilizing such authorial devices. This attitude of Turkish scholars in educational sciences seems to be reinforced by Turkish journal submission guidelines. Out of 20 Turkish education journals we investigated in a recent study (Deveci \& Nunn, 2020), only two had an explicit reference to their expectation of authors to use the active voice. However, one of these journals warned authors that "third person should be used" while the other one had no mention of personal pronoun usage. Left without enough guidance, together with a stereotypical approach to academic writing, many Turkish scholars appear to devoid themselves of linguistic devices that can help establish an authorial voice in their respective fields of study. Gastel and Day (2016), too, note that many scientists opt for the passive voice at the expense of creating an authorial voice for themselves. They call this "a bad habit" resulting from "the erroneous idea it is somehow impolite to use first-person pronouns." Because of this idea, the scientist commonly uses verbose (and imprecise) statements such as, "It was found that" in preference to the short, unambiguous "I found." They encourage (young) scientists to "renounce the false modesty of their predecessors" (p. 202). They ask them not to be afraid to name the agent of the action. Similarly, Alley (2013) also observes that the passive voice is used by many scientists who "cling to the misconception that they can never use the first person" (p. 107) and gives examples of famous scientists such as Einstein, Curie, Darwin, and Freud who used the first-person pronouns. To Alley (2013), it is perfectly fine to use the first person so long as the emphasis is placed upon the work rather than the author.

Research has indeed revealed that authors in hard and social sciences tend to use personal pronouns to explain their research activities (Hyland, 1999). Sword (2012) observes that this helps authors make their sentences "more energetic, more persuasive, and easier to understand" (p. 37). Similarly, Rebecca Oxford, who provided feedback on Nunn's analysis through an electronic mail, noted that this also 
helps authors refrain from "obfuscation, opaqueness, passivity and general stuffiness in writing about research" (Nunn, 2008, p. 222). In her investigations into authorial voice in applied linguistics, Dontcheva-Navratilova (2013), too, found that there is a move towards a more subjective way of expression despite the scientific paradigm suggesting authors ought to refrain from personality for the sake of objectivity. She found that the authors whose native language was English had a greater tendency to utilize the pronoun system for maintaining the writer-reader relationship in comparison to Czech authors. This allowed them an authoritative authorial voice. Based on her results, Dontcheva-Navratilova (2013) argued that "personal structures in academic discourse can function as powerful means of showing the author's attitude to disciplinary practices and disciplinary knowledge, highlighting key problems, emphasizing and negotiating the author's contribution to the field" (p. 28). This supports Hyland's (2002) argument that

[authors] gain credibility by projecting an identity invested with individual authority, displaying confidence in their evaluations and commitment to their ideas. Perhaps the most visible manifestation of such an authorial identity is the use of first-person pronouns and their corresponding determiners. (p. 1091)

Based on results from an empirical study, Harwood (2005) also observed that the first-person singular and plural pronouns are used by authors in both hard and soft disciplines to promote their work. He noted that such devices help authors "market their research from the start, underscoring novelty and newsworthiness in the introduction as they help create a research space" (p. 1226). Their use also contributes to authors' attempt to "be seen as a player in the discourse community" (p. 1226).

\section{Method}

\subsection{Collection of texts}

This descriptive study was based on 62 RAIs from manuscripts published in educational sciences journals in English $(n=31)$ and Turkish $(n=31)$. The convenience sampling method was adopted in selecting the journals. However, a certain set of criteria was used. One of these was that the journals had to be open access. I also made sure that the journals were peer-reviewed. Another criterion I used was that the RAs had to be relatively recent so that the latest trends would be identified. Toward this end, I included articles published between 2012 and 2018. Attention was also paid to choosing introductions of similar nature. That is, introductions with various subheadings were kept outside of the scope of the study. Detailed information about the journals included in this study can be seen in Table 1 below. 
Table 1. Journals included in the collection

\begin{tabular}{|c|c|c|c|}
\hline \multicolumn{2}{|c|}{ Journals } & \multirow{2}{*}{$\begin{array}{l}\text { Number of } \\
\text { Articles }\end{array}$} & \multirow{2}{*}{$\begin{array}{l}\begin{array}{l}\text { Publication } \\
\text { Years }\end{array} \\
2017-2018\end{array}$} \\
\hline \multirow{5}{*}{ 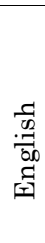 } & Canadian Journal of Education & & \\
\hline & European Journal of Special Education Research & 8 & 2018 \\
\hline & Learning and Teaching in Higher Education: Gulf Perspectives & 8 & $2016-2017$ \\
\hline & PAACE Journal of Lifelong Learning & 6 & $2012-2016$ \\
\hline & Gazi Üniversitesi Gazi Eğitim Fakültesi Dergisi & 6 & $2015-2017$ \\
\hline \multirow{4}{*}{ 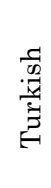 } & Ankara Üniversitesi Eğitim Bilimleri Fakültesi Dergisi & 10 & $2014-2017$ \\
\hline & Bartın Üniversitesi Eğitim Fakültesi Dergisi & 8 & $2018-2019$ \\
\hline & Hacettepe Üniversitesi Eğitim Fakültesi Dergisi & 7 & $2016-2017$ \\
\hline & Total & 62 & $2012-2018$ \\
\hline
\end{tabular}

The complied collection of texts was made up of 358,068 running words. Of this number, 157,233 belonged to the Turkish set, and 200,835 belonged to the English set.

\subsection{Analysis}

All the analyses were carried out manually by the researcher himself in addition to an independent researcher. The analysis of the move structures in the RAIs was conducted considering Swales and Feak's (2012) CARS model, but other variations in the compilation were also noted if repeated with a considerable frequency. At the same time, the authorial voice was investigated considering frequencies. In identifying the authors' utilization of agency, using or avoiding the use of first-person pronouns (i.e., I, we) and possessive adjectives (i.e., my, our), only those referring to authors themselves in highlighting the importance of their studies were considered. For example, the generic use of "we" in the sentence "we know more about how the use of educational applications affect the learning environment" was excluded in the analysis since it is not used to represent the authors' agency.

Similarly, in identifying the uses of the passive voice, only those indicating the authors' engagement in the statements or those that emphasize the rationale/importance of the study were considered: Compare "... a literature review ... will be presented prior to introducing the heart of the analysis" to "Post-secondary education (PSE) is well-documented as being beneficial to individuals and society as a whole." The former refers to an action to be taken by the authors themselves. The latter, on the other hand, refers to factual information outside the author; therefore, it was excluded from the data set.

It appeared during data analysis that other impersonal language usages were also used to express authorial agency albeit a lack of transitivity. Therefore, I also paid special attention to the identification of additional impersonal language use. Examples of such usage in the English texts include "... it is important to $\neq$ decide whether students from both groups of special needs can benefit from the same, similar

+ Emphases added 
or entirely different educational programs" (Ioannis \& Eleftheria, 2018, p. 28) and "The limited research available is in stark contrast to the seriousness of this issue, while also plainly revealing the absence of school-based approaches" (Louie, 2018, p. 635). An example from the Turkish texts, on the other hand, is as follows.

(1) Bunanla birlikte, böylesine kapsamlı ve Türkiye çapında gerçekleştirilen bir proje yarışmasına yönelik araştırmaların ... oldukça sınırlı sayıda olması ise oldukça dikkat çekicidir. Bunlara ek olarak, ilköğretim öğretmenlerinin proje yazma becerilerini geliştirmelerine yönelik TUBITTAK ve MEB tarafından sunulan eğitim faaliyetlerinin olmaması ise dikkat çekicidir. Bu bakımdan, öğretmenlerin, öğrencilerin ve yöneticilerin BBE projeleri ile ilgili karşılaştıkları problemleri, bu problemlerin nedenlerini ve çözüm önerilerini incelemek önemlidir (Özel \& Akyol, 2016, p. 143).

[Along with this, it is interesting to note the limited amount of research conducted into such a comprehensive and Turkey-wide project competition. It is also interesting to note the lack of training activities by TUBITAK and MEB to improve teachers' skills in project writing. Accordingly, it is important to investigate the reasons for and solutions to the problems encountered by teachers, students, and administrators with BBE projects.]

As mentioned above, one other independent researcher with an extensive background in discourse analysis was included in the study to ensure interrater reliability. Overall interrater reliability of $80 \%$ was achieved for the moves. Similarly, overall interrater reliability of $82 \%$ was achieved for the identification of the language-use in regard to the authors' utilization of the passive voice and first-person pronouns. The divergences were discussed, and agreements were reached.

\section{Results}

The first research question aimed to identify and compare the move structures in the two sets of texts. A summary of the results can be seen in Table 2 below.

Table 2. Move structures in the RAIs in Turkish and English

\begin{tabular}{|c|c|c|c|c|c|}
\hline \multicolumn{2}{|c|}{ Moves } & \multicolumn{2}{|c|}{$\begin{array}{l}\text { Turkish set } \\
(\mathrm{N}=31)\end{array}$} & \multicolumn{2}{|c|}{$\begin{array}{l}\text { English set } \\
(\mathrm{N}=31)\end{array}$} \\
\hline & & $\mathrm{f}$ & $\%$ & $\mathrm{f}$ & $\%$ \\
\hline \multirow[t]{2}{*}{1} & $\begin{array}{l}\text { Establishing a research territory by showing that the general research is } \\
\text { important, central, interesting, problematic, or relevant in some way }\end{array}$ & 31 & 100 & 31 & 100 \\
\hline & $\begin{array}{l}\text { Establishing a research territory by introducing and reviewing items of } \\
\text { previous research in the area }\end{array}$ & 23 & 74.2 & 30 & 96.8 \\
\hline 2 & $\begin{array}{l}\text { Establishing a niche by indicating a gap in the previous research or by } \\
\text { extending previous knowledge in some way }\end{array}$ & 26 & 83.9 & 30 & 96.8 \\
\hline \multirow[t]{6}{*}{3} & $\begin{array}{l}\text { Occupying the niche by outlining purposes or stating the nature of the present } \\
\text { research }\end{array}$ & 24 & 77.4 & 31 & 100 \\
\hline & Occupying the niche by listing research questions or hypotheses & 2 & 6.5 & 7 & 22.6 \\
\hline & Occupying the niche by announcing principal findings & 0 & 0 & 4 & 12.9 \\
\hline & Occupying the niche by stating the value of the present research & 16 & 51.6 & 26 & 83.9 \\
\hline & Occupying the niche by indicating the structure of the research paper & 3 & 9.7 & 5 & 16.1 \\
\hline & Occupying the niche by describing the methodology used & 0 & 0 & 6 & 19.4 \\
\hline
\end{tabular}


The first move identified in the CARS model is establishing a research territory. This is done by showing that the general research is important, central, interesting, problematic, or relevant in some way. Although Swales and Feak (2012) identified this as an optional move, it was present in all the introductions in both sets of texts. According to the CARS model, the research territory can also be established by introducing and reviewing items of previous research in the area. This is, in fact, obligatory in the model. However, it was present in only $74.2 \%$ of the Turkish set and $96.8 \%$ of the English set. A similar result was found relative to the second move requiring that authors establish a niche by indicating a gap in the previous research or by extending previous knowledge in some way. This was present in only $83.9 \%$ of the Turkish set but $96.8 \%$ of the English set.

The third move in the CARS model is occupying the niche. This can be done in a variety of ways. One of these is by outlining purposes or stating the nature of the present research. Although this is an obligatory move, only $77.4 \%$ of the Turkish set included this move, while it was present in all 31 RAIs in the English set. This move can also be performed by listing research questions and/or hypotheses. Used relatively less frequently, this was present only in two RAIs in the Turkish set (6.5\%) and seven (22.6\%) in the English set. Another way in which the third move can be performed is by announcing the main findings. Again, this was quite uncommon in the set of texts. This was non-existent in the Turkish set and present in only four of the RAIs (12.9\%) in the English set.

According to the CARS model, the third move can also be performed by stating the value of the present research. As is seen in Table 3, this was comparatively more popular than the two previous ways in both sets of texts. That is, $56 \%$ of the Turkish set and $83.9 \%$ of the English set opted for this way of indicating how the niche would be occupied. However, as is reflected by the percentages, it was more popular with the authors writing in English.

Indicating the structure of the research paper is another way in which authors may choose to mention how the niche will be occupied. This was not common in either of the sets. That is, only $9.7 \%$ of the Turkish set and $16.1 \%$ of the English set opted for it. Slightly more authors in the latter group tended to indicate the structure of the research paper.

The analysis of the data in this study revealed one additional move in the English set: indication of methodology. Six of the English RAIs (19.4\%) mentioned the methodology adopted for their investigation. It was absent in the Turkish.

The second research question aimed to describe the authorial voice used in the introduction sections of education RAs in English and Turkish. A summary of the results for this purpose can be seen in Table 3 below. 
Table 3. Authorial voice in RAIs

\begin{tabular}{llll}
\hline Authorial Voice & $\begin{array}{l}\text { English set } \\
\text { (f) }\end{array}$ & $\begin{array}{l}\text { Turkish set } \\
\text { (f) }\end{array}$ \\
\hline Active voice & First-person pronoun & 29 & 0 \\
& Impersonal active voice & 121 & 54 \\
& Total & 150 & 54 \\
Passive voice & 76 & 116 \\
Overall total & 226 & 170 \\
Ratio of active voice to passive voice & $66 \%-34 \%$ & $32 \%-68 \%$ \\
\hline
\end{tabular}

Table 3 shows that there was a total of 150 occurrences of the active voice use in the English set. Of this number, 121 belonged to the impersonal active voice use. These included phrases embedding the demonstrative pronoun "this" and the definitive article "the," as in "this research," "the current/present study," and "this article." Slightly more than half of the impersonal active voice use (64) included these morphemes. These were often used in the active voice. Sample sentences are as follows from Michael and Gorpe (2017):

(2) The main aim of this paper is to highlight the importance for students of learning outside the classroom environment.

(3) The paper explores the benefits of learning from a workshop event organized by students as part of a class assignment with the Middle East Public Relations Association

(4) This study is particularly significant since it involves the United Arab Emirates (UAE), a new country where public relations development and education are new. (p. 2)

Some authors also used dummy subject "it," as in “...it is important to conduct research that will provide insight into transformative resistance through education" (Louie, 2018, p. 637) and "... it is important to understand how to promote such skills, as well as to explore ways to contribute to their better development" (LaForge et al., 2018 , p. 304). The significance of the study was also pointed out by some authors through modal verbs, as in "Developing an understanding of what works and what does not in the UAE will point towards strategies that could positively impact teaching practices in the Middle East and other globalist contexts" (Causapin \& Groombridge, 2017, p. 2) and "Again, a thorough understanding of the process by which students choose their majors could feed into the growing campaign to develop a scenario for addressing the root cause of the lack of popularity ..." (Mishra, Ahmed, \& Al Hadabi, 2017, p. 2).

The Turkish set included similar uses. The demonstrative pronoun "bu [this]" was often used together with nouns "araştırma [research]," and "çalışma [study]." These accounted for 37 of the total 54 impersonal active voice uses in the Turkish set. The adjective "önemli [important]" is also used to emphasize the significance of the study. It is often used with intensifiers such as "oldukça [quite]." Example sentences are as follows: 
(5) Oysaki farklı kavramları ve kuramları bir araya getirerek öğrencilerin öğrenme süreçlerini daha kapsamplı bir şekilde açıklamaya çalışmak, öğrenme-öğretme sürecine doğru müdahele edebilmek açısından oldukça önemlidir. (Beyaztaş \& Şahin, 2017, p. 64)

[However, it is very important to clarify students' learning processes by bringing together various concepts and theories so that appropriate action can be taken to improve the learning-teaching process.]

(6) ... öğretmenlerin, öğrencilerin ve yöneticilerin BBE projeleri ile ilgili karşılaştıkları problemleri, bu problemlerin nedenlerini ve çözüm önerilerini incelemek önemlidir. (Özel \& Akyol, 2016, p. 143)

[... it is important to investigate the reasons for and solutions to the problems encountered by teachers, students, and administrators with BBE projects.]

(7) ... çocuklara içinde yaşadıkları çevreyi sorgulama ve yaşayacağı yeri seçmeye yönelik en azından temel becerilerin sağlanması önem taşımaktadır. (Acar, 2016, p. 66)

[...it is important to teach children at least the basic skills in questioning the environment in which they live and the places where they will live.]

The Turkish and English data sets revealed that the overall use of the impersonal active voice was more common in the latter. The case was similar regarding the use of the personal active voice. None of the authors of the texts in the Turkish set utilized first-person pronouns. The English set, on the other hand, exhibited a variety of such pronouns: I $(n=14)$, we $(n=7)$, my $(n=5)$, our $(n=2)$, us $(n=1)$. The following examples are from Louie (2018):

(8) Findings from research I conducted from 2014 to 2016 (Louie, 2016), as a part of a larger study, highlight the schools' lack of attention to the issue of the overrepresentation of sexually exploited Indigenous girls. (p. 635)

(9) Based on my findings, I have endeavoured to fill the gap by developing the foundations of school-based approaches for prevention education. (p. 635)

(10) To answer these questions, I conducted case study research in Prince Albert... . (p. 636)

(11) My primary aim in this study was to establish evidence-based curriculum recommendations for prevention education grounded in the knowledge of Indigenous women who have experienced sexual exploitation. (p. 636)

The following two examples are from Howe (2016):

(12) Having taught writing and English courses at the community college level for seven years, too frequently I encountered underachieving students at risk of failure-students who were clearly capable of personal and academic success. (p. 52)

(13) In this study, I examine student resistance and offer examples of student redefinition of self (Foucault \& Rabinow, 1997) through the creative writing workshop (Nichols, 2007). (p. 52)

In Patrick, Gulayets, and Peck (2017), the following uses of the first-person plural pronouns were identified: 
(14) Our findings led us to divide teachers into three categories based on their views of religion in the curriculum and classroom .... (p. 607)

(15) We begin with an explanation of how we use the term "religion," followed by ... . (p. 607)

The passive voice as an impersonal structure was used in both English and Turkish sets. The following English example is from Maajeeny (2018):

(16) Therefore, screening for children with E/BD in Saudi Arabia is an initiative which must be undertaken to estimate the extent to which E/BD interventions are needed. (p. 50)

The following Turkish example is from Ayvacı, Atik, and Ürey (2016):

(17) $\mathrm{Bu}$ durumda okul öncesi çocukları için bilim kavramını nasıl algıladıklarını ortaya koymak ancak bilimin temsilcileri olan bilim insanlarını nasıl algıladıklarıyla anlaşılabilir. (p. 670)

[How preschool children perceive the concept of science can only be understood by identifying their perceptions of scientists who are the representatives of science.]

However, the passive voice was used much more frequently in the Turkish set than the English one (116 vs. 76). The Turkish authors' heavy reliance on the passive voice in comparison to the active voice is important to note (32\% vs. $68 \%$ ). The case in the English set is almost the reverse (66\% vs. 34\%). Taken together, these results indicate that the authors of the English texts had a greater tendency to express their authorial voice through the active voice, and the number of the first-person pronouns in the active voice was important to note too.

\section{Discussion}

The first research question aimed to identify and compare the move structures in English and Turkish education RAs. Results showed that there was overall more frequent use of the moves in the English set. This was except for the first move requiring authors to establish their research territories by showing the general research is important, interesting, relevant, etc. Swales and Feak (2012) indicate that this is an optional move; however, the fact that it was present in both the English and Turkish data sets in the current study indicates that it may be regarded as an obligatory move in education RAs. Yet the number of RAs included in the study limits the generalizability of this deduction, pointing to the need for further studies.

A significant difference between the English and Turkish data sets was related to stating the value of the present research. In the English data set $83.9 \%$ included this move whereas only $51.6 \%$ of the latter included it. The difference between the two sets may be attributable to the perception of modesty in Turkish culture, which considers modesty to be a politeness strategy. According to the Anatolian culture in particular, those who are sure of themselves refrain from praising themselves (Candan, 2007). Prompted by a similar attribute, a significant number of the Turkish authors whose papers were investigated in this study may have chosen not to state the value of their studies in the introduction. They may have thought that doing otherwise would have threatened their face, which is defined as "public self-image that every member of a 
society wants to claim for himself [or herself]" (Brown \& Levinson, 1987, p. 66). Other researchers have also observed that authors in the Turkish context are often expected to display modesty and humbleness without "go[ing] beyond the limits of appropriate academic writing whose lines are not clearly visible but dependent on reviewers' openness for change and creativity" (Yaylı \& Canagarajah, 2018, p. 120).

The absence of certain other obligatory moves in more of the Turkish introductions than in the English introductions is also important to note. Comparatively fewer Turkish authors established their research territory by introducing and reviewing items of previous research in the area (23 vs. 30 ), established a niche by indicating a gap in the previous research (26 vs. 30), and occupied the niche by outlining the purpose(s) of their research (24 vs. 31). Together with the above-mentioned finding related to stating the value of the present research, these results further point to the Turkish authors' reduced tendency to emphasize the significance of their present research. This, again, could be attributed to the authors' use of politeness strategies. Limited attention drawn to the importance of a study in the introduction may be problematic since it is in this section that readers expect to be able to make their decisions on why the work is important. Despite this, there is at least some warning in the literature that there may be other reasons (e.g., the nature of the work or the target audience) why authors may either avoid providing an answer to their readers' questions, or they provide an indirect answer (Alley, 2013). As is indicated by the results of the current study, neither seemed to be the case for the authors of the papers in English.

Pressured by promotional concerns as well as the desire to reach a wider circle of audiences, Turkish scholars often submit their papers to international journals which publish articles in English. If articles are translated from authors' native language into English without due consideration of style differences between the languages, submissions are likely to be returned to authors for (major) revisions, or they may simply be rejected. In fact, the utilization of fewer moves in the Turkish data set in comparison to the English set appears to be reflected in introductions in English written by non-native speakers and ESL students in other contexts. Maznun, Monsefi, and Nimehchisalem (2017), for instance, found that ESL students faced difficulties in incorporating the moves in their writing in general, and Move 2 in particular, failing to establish a niche for their research. In another study, Hüttner (2015) investigated university students' awareness of genre. To this end, the researcher collected data on the students' understanding of communicative purposes in writing RAIs. Although the students pointed to the importance of getting the readers interested, their written papers failed to include move realizations directly representing this purpose. Some highlighted their interest in the topic with only an implicit assumption that the readers would share this interest. Likewise, Gupta (1995) found that ESL students were overall able to follow the moves in the CARS model; however, they still faced other challenges dealing with different levels of information, and transitioning between levels of information, resulting in a lack of complete coherence in their introductions. In a more recent study, Fudhla, Rozimal, and Ningsih (2014) studied 
students' skills in writing research proposals. They found that the students faced difficulties narrowing down the research area. The students also repeated Move 1 too frequently to highlight the importance of their chosen topics. Only a small number of the students were able to establish a niche for their research. Move 3, on the other hand, was poorly managed due to the students' ineffective use of the English language. The researchers reasoned that this might be due to the students' lack of understanding of the type of research they were to conduct. Collectively, these studies point to the need for concentrated efforts to improve non-native authors' skills in writing RAIs.

The second research question was related to authorial voice, which can be expressed in a variety of ways. Results revealed that Turkish authors established their voice using mainly the passive voice and the impersonal active voice. This was in stark contrast to the authorial voice established in the English set of texts where the active voice was used more often than the passive voice. Unlike the Turkish set of texts, the English set exhibited the first-person pronouns as well, albeit less frequently. The authors of the papers analyzed in the current study probably chose to use the passive voice and the impersonal active voice due to "the erroneous idea it is ... impolite to use first-person pronouns" (Gastel \& Day, 2016, p. 202). Previous research also showed Turkish authors' reluctance to exploit the first-person pronouns when writing in English as a foreign language. For example, İşler (2018) found that Turkish master's students' use of personal pronouns was rather limited. Even when they were used, they were used for a narrower range of functions without expressing authorial identity. İşer (2018) reasoned that this was probably because of "some vague preconceived notion of impersonal and distant academic writing" (p. 19). Similarly, Işık-Taş (2008) also found the introduction sections of English doctorate dissertations written by Turkish authors only rarely included authors' presence. When some authors did express presence, they did so rather impersonally, referring to themselves as "the/this researcher" or "this author." Işık-Taş (2010) notes that expert and novice authors' utilization of the first-person pronouns often differs. While the former utilize them to promote their work, the latter either underuse them or use them for functions rarely preferred by the former. When the strategic use of the firstperson pronouns to highlight an original contribution to the field is considered (Nunn et al., 2018; Hyland, 2002; Dontcheva-Navratilova, 2013), the Turkish authors' reluctance to use this linguistic device draws more attention. Coupled with the abovediscussed result related to the authors' somewhat limited dexterity in stating the value of their research, this finding is noteworthy. The authors' eagerness to use the passive voice, as well as other impersonal active voice forms, at the expense of "transparent authorial intervention" (Nunn, 2012, p. 33) can limit their potential to express their authorial voice as the researchers of the article and underline their contribution to their academic community (Kuhi, Tofigh, \& Mabaie, 2013; DontchevaNavratilova, 2013). It also impedes the readers' attempt to decide what can be retained and relied upon for future study (Nunn et al., 2018). 
I also suspect that the authors' choice of using transitivity may not always be based on free choice. This is supported by a recent study we conducted into the first-person pronoun usage in the method sections of education RAs (Deveci \& Nunn, 2020). We found that Turkish authors often felt obliged to abstain from using personal language (particularly the first-person pronouns) in an attempt to have their papers accepted for publication. It is, therefore, safe to argue that it is misleading to label being transparent about agency as "subjective" when it more honestly represents the reality of the research process in question and presents our assumptions clearly (Deveci \& Nunn, 2020).

\section{Conclusions}

Results of this study point to a general pattern in education RAIs in English and Turkish. It is important that scholars and training students be informed about the general trends in their discourse community. "A discourse community has [particular] mechanisms of intercommunication among its members" (Swales, 1990, p. 471), and successful communication within one's discourse community requires effective use of these mechanisms. Among these are the aspects of scholarly writing investigated in this study: move structure and language use for establishing an authorial voice. According to Grice's (1989) Cooperative Principle (CP), those involved in communication (may it be written or spoken) need to "make their ... contribution such as is required, at the stage at which it occurs, by the accepted purpose or direction of [communication] in which [they] are engaged" (p. 26). Grice considers CP as a "super principle' embedding four maxims. One of these is 'quality,' which requires authors to provide enough evidence for their arguments. In the case of an RA, establishing the relevance and significance of the present research from the outset necessitates evidence in the form of reference to previous research, for instance. Identification of and adherence to the ways in which this maxim, along with the other three (i.e., 'quantity,' 'relation,' and 'manner'), are addressed in scholarly publications is important.

With the desire to become more promotable and visible in their disciplines, many Turkish scholars are encouraged to publish in English. This is also often promoted by the conviction that "English is the language of science" (Englander, 2014, p. 3). As is indicated by the results of the current study, there are significant differences between how the introduction section is written in Turkish and English. If authors lose sight of these differences and write the same way as they do in their native tongues, their publication chances may be limited, or they may experience lengthy review processes. It is, therefore, necessary to consider how authors write in their respective genres using the target foreign language. It is also important to consider the expectations of the journals to which they submit their manuscripts for a possible publication. It appears that education journals generally instruct authors to follow APA in preparing their manuscripts. Note that APA (2010) favors the active voice as well as personal pronouns where relevant. This helps avoid ambiguity. Despite this, journal editors may still insist authors avoid using personal language. This appears to be particularly 
the case among Turkish academia. Scholars must be better guided about establishing their authorial voice in different ways. Implicit or explicit prohibition of authors from utilizing personal language for the sake of being 'objective' would limit authors' transitivity choices, thus reducing their chances of highlighting the significance of their present research (Deveci \& Nunn, 2020).

Several actions can be taken in writing-focused classes to increase students' awareness of the CARS model. One of these is through reordering exercises that require students to reorder jumbled sentences from the introduction section of a particular publication (Martin-Martin, 2013). Subsequent discussion can be held on possible variations to the original order and how it would impact the message. Students can also be asked to explain if they would similarly organize ideas in their native language. Similarities and differences could be discussed. Additionally, students' attention could be drawn to the discourse conventions of each move of a prototypical text (Martin-Martin, 2013). To this end, different types of fill-in-theblank exercises can be used. Asking students to draft an outline reflecting each move would also help them organize their introductions according to the CARS model. In addition, students can be asked to compare introductions from different disciplines or sub-disciplines. This would help them notice disciplinary variations.

Writing classes can also focus on authorial voice. Students can be asked to do quantitative and qualitative analyses of various language elements in particular introductions, including the first-person pronouns, the impersonal active-voice use, and the active voice vs. the passive voice. To this end, a variety of software can be utilized. An example is AntConc, which allows users to create their corpus for various types of analyses. Another online tool can be found at http://www4.caes.hku.hk/vocabulary/tools_cp.htm. Not only does this tool help identify the frequency of word occurrences, but it also allows researchers to find examples of the usage of particular words or parts of words in a text through its concordancer application. The students can use this tool to identify how many times a certain personal pronoun appears in the text. The concordancer, on the other hand, can help with qualitative analyses as well as assist in identifying how different moves and submoves are introduced in the text.

Paraskevas (2006) proposed a similar teaching approach called "Grammar Apprenticeship". In this approach, students analyze grammatical structures used by proficient authors. Their awareness is raised concerning the choices authors make at the sentence level. This helps students develop "a feel for the beauty of language, for its power and strength and grace" (p. 65). When they engage in stylistic analysis of such texts, students notice stylistic effectiveness. They are asked to revise their papers accordingly. This experience allows them to write their sentences and improve the tone of voice in their writing. They learn to make informed decisions about how to express factual information as well as their ideas and feelings. This supports Krashen's (1984) view that competent writing skills are normally acquired as a result of engagement in extensive reading of texts composed by competent authors. 
Another way to help students establish an authorial voice is through paraphrasing exercises. Students can be asked to restate sentences in the passive voice using the active voice. They may be required to use the personal pronouns where relevant. Another paraphrasing activity can be in the format of editing (Deveci, 2019). For this purpose, students can be provided a short text devoid of much authorial voice and be asked to rephrase sentences/phrases using appropriate ones from a given list.

Students can also be given small projects requiring them to analyze author guidelines of certain journals in their disciplines. They may be asked to pay closer attention to the language use expected by the journals they have been assigned. They would then be instructed to present their findings to the class. A similar approach can be taken with the writing standards set by publication manuals.

One limitation of this study is that it only included 62 RAs (31 in Turkish and 31 in English). Results, therefore, cannot be generalized to the wider discourse community. This study should be considered as a preliminary one. However, future studies can increase the sample size to help increase generalizability. Also, this study investigated the introduction section of RAs. Authors' use of authorial voice in different sections of RAs can be compared. Comparison can also be made between different disciplines as well as between subfields of a particular discipline.

\section{Acknowledgments}

This research was supported by Limitless Education and Research Association, Ankara, Turkey. Project number: SEADBAP2018-3

\section{References}

Acar, D. (2016). Çocuk ve mimarlık: Küçük çocuklar için mimari tasarım öğretimi programı. Hacettepe Üniversitesi Eğitim Fakültesi Dergisi, 30(1), 66-81.

Adika, G. S. K. (2014). Swales' CARS model and the metaphor of research space: An illustration with an African journal. Legon Journal of the Humanities, 25, 58-75. http://dx.doi.org/10.4314/ljh.v25i1.4

Afshar, H. S., Doosti, M., \& Movassagh, H. (2018). A genre analysis of the introduction section of applied linguistics and chemistry research articles. Iranian Journal of Applied Linguistics, 21(1), 163-214.

Alley, M. (2013). The craft of scientific writing. New York, NY: Springer.

American Psychological Association. (2010). Publication manual of the American Psychological Association (6th ed.). Washington, DC: Author.

Anthony, L. (1999). Writing research article introductions in software engineering: How accurate is a standard model? IEEE Transactions on Professional Communication, 42(1), 38-46.

Arvay, A., \& Tanko, G. (2004). A contrastive analysis of English and Hungarian theoretical research article introductions, IRAL, 42(1), 71-100.

Ayvacı, H. Ş., Atik, A., \& Ürey, M. (2016). Okul öncesi çocuklarının bilim insanı kavramına yönelik algıları. Bartın Üniversitesi Eğitim Fakültesi Dergisi, 5(3), 669-689. 
Beyaztaş, D. İ., \& Şahin, S. G. (2017). Öğrenme yaklaşımları ile öğrenme stratejilerini kullanma kalitesi arasındaki ilişkilerin modellenmesi. Ankara Üniversitesi Ĕ̈itim Bilimleri Fakültesi Dergisi, 50(2), 59-78.

Brown, P. \& Levinson, S. C. (1987). Politeness: Some universals in language usage. Cambridge, England: Cambridge University Press.

Candan, E. (2007). Türklerin kültür kökenleri. İstanbul: Sınır Ötesi Yayınları.

Carciu, O. M. (2009). An intercultural study of first-person plural references in biomedical writing. Ibérica, 18, 71-92.

Cargill, M., \& O'Connor, P. (2013). Writing scientific research articles: Strategy and steps (2nd ed.). West Sussex, UK: Wiley-Blackwell.

Causapin, M., \& Groombridge, T. (2017). The effects of language simplification and pictures on the ability of Emirati university students to comprehend and solve mathematics word problems. Learning and Teaching in Higher Education: Gulf Perspectives, 14(2). http//doi.org/10.18538/lthe.v14.n2.288

Chandrasegara, A. (2012). Empowering second-language writers through rhetorical move analysis. In C. Gitsaki, \& R. B. Baldauf Jr. (Eds.), Future directions in applied linguistics: Local and global perspectives (pp. 10-25). Newcastle, England: Cambridge Scholars Publishing.

Crookes, G. (1986). Towards a validated analysis of scientific text structure. Applied Linguistics, 7, 57-70.

Deveci, T. (2019). Sentence openers in academic writing: A comparison between seminar texts and students' reflective writing papers. Journal of Language and Linguistic Studies, 15(1), 247-261.

Deveci, T., \& Nunn, R. (2018). Use of relative clauses in humanities and social sciences research articles: A case study. Linguistics and Literature Studies, 6(1), 17-26. http://dx.doi.org/10.13189/1ls.2018.060103

Deveci, T., \& Nunn, R. (2020). First person pronouns in method section of education research articles: The case of Turkish scholars. In O. Mentz \& K. Papaja (Eds.), Focus on Language: Challenging Language Learning and Language Teaching in Peace and Global Education (pp. 286-311). Münster: LIT Verlag volume 10 of the book series: Europa lernen. Pespektiven für eine Didaktik europäischer Kulturstudien.

Dontcheva-Navratilova, O. (2013). Authorial presence in academic discourse: Functions of author-reference pronouns. Linguistica Pragensia, 23(1), 9-30.

Dudley-Evans, T. (2000). Genre analysis: A key to a theory of ESP? Ibérica, 2, 3-11.

Englander, K. (2014). Writing publishing science research papers in English: A global perspective. Toronto, Canada: Springer. https://doi.org/10.1007/978-94-007-7714-9

Fudhla, N., Rozimela, Y., \& Ningsih, K. (2014). An analysis of students' research proposal introduction based on CARS model at STAIN Sjech M. Djamil Djambek Bukittinggi. Journal English Language Teaching, 2, 66-77.

Gastel, B., \& Day, R. A. (2016). How to publish a scientific paper (8th ed.). Santa Barbara, CA: Greenwood.

Grice, H. P. (1989). Studies in the way of words. Cambridge, MA: Harvard University Press.

Gupta, R. (1995). Managing general and specific information in introductions. English for Specific Purposes, 14(1), 59-75.

Habibie, P. (2008). Genre analysis of research article introductions across ESP, Psycholinguistics, and Sociolinguistics. Iranian Journal of Applied Linguistics, 11(2), 87-111. 
Harwood, N. (2005). 'Nowhere has anyone attempted ... In this article I aim to do just that': A corpus-based study of self-promotional I and we in academic writing across four disciplines. Journal of Pragmatics, 37(8), 1207-1231.

Hirano, E. (2009). Research article introductions in English for specific purposes: A comparison between Brazilian Portuguese and English. English for Specific Purposes, 28(4), 240-250.

Howe, L. (2016). Resistance, transformation, and identity: Replacing at-risk patterns with agency through the creative writing workshop. PAACE Journal of Lifelong Learning, 25, 51-67.

Hüttner, J. (2015). Communicative purpose in student genres: Evidence from authors and texts. Fremdsprachen Lehren und Lernen, 44(1), 29-43.

Hyland, K. (1999). Disciplinary discourses: Writer stance in research articles. In C. Candlin \& K. Hyland (Eds.), Writing: Texts, processes and practices (pp. 99-121). London, England and New York, NY: Longman.

Hyland, K. (2002). Authority and invisibility: Authorial identity in academic writing. Journal of Pragmatics, 34, 1091-1112.

Ioannis, A., \& Eleftheria, I. (2018). Comparison of students with non-verbal learning disabilities and students with Asperger syndrome in solving word arithmetic problems. European Journal of Special Education Research, 3(3), 27-48.

Işı-Taş, E. (2008). A corpus-based analysis of genre-specific discourse of research: The research article and the PhD thesis in ELT (Unpublished PhD Dissertation). Middle East Technical University, Ankara.

Işık-Taş, E. (2010). "In this paper I will discuss...”: Current trends in academic writing. Procedia Social and Behavioral Sciences, 3, 121-126.

İşler, C. (2018). The use of first person pronouns in master's theses written in English by Turkish authors. Journal of English and Education, 4(1), 12-20.

Jalilifar, A., Hayati, A. M., \& Namdari, N. (2012). A comparative study of research article discussion sections of local and international applied linguistics journals. The Journal of Asia TEFL, 9(1), 1-29.

Kafes, H. (2012). Cultural traces on the rhetorical organization of research article abstracts. International Journal on New Trends in Education and Their Implications, 3(3), 207-220.

Krashen, S. (1984). Writing: Research, theory and application. Oxford, England: Pergamon Institute of English. https://doi.org/10.1017/s0272263100006197

Kuhi, D., Tofigh, M., \& Babaie, R. (2013). Writers' self-representation in academic writing: The case of computer engineering research articles by English versus Iranian writers, International Journal of Research Studies in Language Learning, 2(3), 35-48.

LaForge, C., Perro, M., Roy-Charland, A., Roy, E. M., \& Carignan, I. (2018). Contributing to children's early comprehension of emotions: A picture book approach. Canadian Journal of Education, 4(1), 301-328.

Loi, C. K., \& Evans, M. S. (2010). Cultural differences in the organization of research article introductions from the field of educational psychology: English and Chinese. Journal of Pragmatics, 42(10), 2814-2825.

Louie, D. (2018). Sexual exploitation prevention education for indigenous girls. Canadian Journal of Education, 41(2), 633-663.

Maajeeny, H. (2018). Children with emotional and behavioral disorders in Saudi Arabia: A preliminary prevalence screening. European Journal of Special Education Research, 3(3), 49-77. 
Martin-Martin, P. (2013). The teaching of academic writing to English as a second language students: A functional genre-based approach. Revista de Lenguas para Fines Específicos, 19, 329-351.

Maznun, M. D. B., Monsefi, R., \& Nimehchisalem, V. (2017). Undergraduate ESL students' difficulties in writing the introduction for research reports. Advances in Language and Literacy Studies, 8(1), 9-16.

McCallum, L. (2016). Exploring authorial presence through the use of first person pronouns: Evidence from a Saudi university. Arab World English Journal, 7(2), 118-135.

Merriam-Webster.com. (2019). Retrieved from https://www.merriamwebster.com/dictionary/introduce

Michael, N., \& Gorpe, T. S. (2017). Public relations for the next generation: Middle East Public Relations Association (MEPRA)'s engagement with students. Learning and Teaching in Higher Education: Gulf Perspectives, 14(2). http//dx.doi.org/10.18538/lthe.v14.n2.268

Mishra, N., Ahmed, I. A., \& Al Hadabi, S. J. (2017). A major choice: Exploring the factors influencing undergraduate choices of communication major. Learning and Teaching in Higher Education: Gulf Perspectives, 14(2). http//doi.org/10.18538/lthe.v14.n2.292.

Nunn, R. (2008). Do academic reviewers readily accept a first-person voice? Asian EFL Journal, 10(2), 210-229.

Nunn, R. (2012). In search of a personal voice: A tale of two papers. In J. Adamson \& R. Nunn (Eds.). Editorial and authorial voices in EFL academic journal publishing (pp. 31-43). Australia: Asian EFL Journal Press.

Nunn, R. (2014). Holistic learning, first-person voice and developing academic competence. Asian EFL Journal, 74, 19-32.

Nunn, R., Brandt, C., \& Deveci, T. (2018). Transparency, subjectivity and objectivity in academic texts. ESBB English Scholarship Beyond Borders, 4(1), 71-102.

Nunn, R., Deveci, T., Khan, I., \& Ayish, N. (2018). A transitivity investigation of Nature journal articles. The Linguistics Journal, 12(1), 192-220.

Özel, M., \& Akyol, C. (2016). Bu benim eserim projeleri hazırlamada karşlaşılan sorunlar, nedenleri ve çözüm önerileri. Gazi Üniversitesi Gazi Eğitim Fakültesi Dergisi, 36(1), 141173.

Öztürk, I. (2007). The textual organization of research article introductions in applied linguistics: Variability within a single discipline. English for Specific Purposes, 26(1), 25-38.

Paraskevas, C. (2006). Grammar apprenticeship. The English Journal, 95(5), 65-70. https://doi.org/10.2307/30046591

Patrick, M., Gulayets, V., \& Peck, C. L. (2017). A call for teacher professional learning and the study of religion in social studies. Canadian Journal of Education, 40(4), 603-637.

Rahman, M., Darus, S., \& Amir, Z. (2017). Rhetorical structure of introduction in applied linguistics research articles. EDUCARE: International Journal for Educational Studies, $9(2), 69-84$.

Samraj, B. (2002). Introductions in research articles: Variations across disciplines. English for Specific Purposes, 21, 1-17.

Shank, G., \& Brown, L. (2007). Exploring educational research literacy. New York, NY: Routledge.

Shehzad, W. (2006). Computer scientist's approach to "establishing a research territory." Selected Papers from the Fifteenth International Symposium on English Teaching. Taipei, Taiwan: Crane Publishing and ETA-ROC. 
Sheldon, E. (2011). Rhetorical differences in RA introductions written by English L1 and L2 and Castilian Spanish L1 writers. Journal of English for Academic Purposes, 10(4), 238251.

Stoller, F. L., \& Robinson, M. S. (2013). Chemistry journal articles: An interdisciplinary approach to move analysis with pedagogical aims. English for Specific Purposes, 32, 45-57.

Swales, J. (1990). Genre analysis: English in academic and research settings. Cambridge, U.K.: Cambridge University Press.

Swales, J., \& Najjar, H. (1987). Research on introductions to research articles. Written Communication, 4(2), 175-191.

Swales, J. M., \& Feak, C. B. (2012). Academic writing for graduate students: Essential skills and tasks (3rd Ed.). Ann Arbor, Michigan: Michigan ELT.

Sword, H. (2012). Stylish academic writing. Cambridge: Harvard University Press.

van Weijen, D. (2014, September 29). How to overcome common obstacles to publishing in English. Retrieved from https://www.elsevier.com/authors-update/story/publishingtips/how-to-overcome-common-obstacles-to-publishing-in-english

Yayll, D., \& Canagarajah, A. S. (2018). The processes behind RA introduction writing among Turkish arts and science scholars. In Y. Kırkgöz \& K. Dikilitaş (Eds.). Key issues in English for specific purposes in higher education (pp. 111-128). Cham, Switzerland: Springer.

\section{Copyrights}

Copyright for this article is retained by the author(s), with first publication rights granted to the Journal.

This is an open-access article distributed under the terms and conditions of the Creative Commons Attribution license (CC BY-NC-ND) (http://creativecommons.org/licenses/by-nc-nd/4.0/). 